\title{
STRATEGI PEMBANGUNAN NASIONAL DALAM UPAYA MENINGKATKAN PERLINDUNGAN DAN PEMAJUAN HAM
}

Oleh :

Nurlely Darwis, Sh, MSi.

\begin{abstract}
Abstrak:
Mencermati situasi negara akhir-akhir ini, umumnya orang akan berpendapat bahwa salah satu permasalahan pokok yang belum terpecahkan didalam proses menjadi "Negara Bangsa Indonesia" yang telah berusia lebih dari setengah abad, adalah terbentuknya sebuah sistem politik demokratis yang berlandaskan pada nilai persatuan dan kesatuan, kebangsaan dan integrasi sosial yang mampu beradaptasi dengan proses perubahan global dengan memperhatikan issu hak asasi manusia. Persepsi rakyat Indonesia sehari- hari terhadap situasi negara pada dasarnya mengalami berbagai macam pendapat, baik secara politis maupun secara sosial mengingat begitu banyak terjadi gejolak sosial bahkan situasi yang mengarah pada terjadinya pelanggaran hak asasi manusia, yang seakan-akan hal itu sudah merupakan pemandangan sehari- hari dan lumrah saja
\end{abstract}

\section{PENDAHULUAN}

Dalam mencermati situasi negara akhirakhir ini, umumnya orang akan berpendapat bahwa salah satu permasalahan pokok yang belum terpecahkan didalam proses menjadi "Negara Bangsa Indonesia" yang telah berusia lebih dari setengah abad, adalah terbentuknya sebuah sistem politik demokratis yang berlandaskan pada nilai persatuan dan kesatuan, kebangsaan dan integrasi sosial yang mampu beradaptasi dengan proses perubahan global dengan memperhatikan issu hak asasi manusia.

Mengingat salah satu perjuangan yang bersentuhan dengan hak asasi manusia dan menjadi faktor utama negara Indonesia adalah "Kebangsaan", maka nasionalisme harus dipelihara agar tetap relevan menghadapi tantangan jaman. Oleh karena itu kondisi yang cenderung tampak sebagai merosotnya nilai kemanusiaan dan sekaligus merendahkan nilai nasionalisme pada dasarnya akan membahayakan kelangsungan hidup bangsa dan Negara Indonesia, yang selanjutnya bila gagal dalam upaya menanamkan rasa kebangsaan dan semena- mena dalam tataran pelaksanaan penyelenggaraan negara, maka kondisi ini akan membuka peluang bagi timbulnya kecemburuan, ketidakpuasan, konflik sosial, disintegrasi bangsa, separatisme dan 
lainnya. Gejala- gejala sosial yang timbul ini pada dasarnya lebih merupakan manifestasi atau akibat dari terpuruknya rasa kebangsaan, selanjutnya kondisi ini dapat menjadi penyebab atau pendorong terjadinya keretakan solidaritas bangsa atau kesatuan dan persatuan bangsa.

Persepsi rakyat Indonesia sehari- hari terhadap situasi negara pada dasarnya mengalami berbagai macam pendapat, baik secara politis maupun secara sosial mengingat begitu banyak terjadi gejolak sosial bahkan situasi yang mengarah pada terjadinya pelanggaran hak asasi manusia, yang seakan- akan hal itu sudah merupakan pemandangan sehari- hari dan lumrah saja. Namun demikian umumnya rakyat dapat berkesimpulan bahwa penyebab terpenting terjadinya gejolak sosial dalam masyarakat adalah karena terjadi kesenjangan dan ketidak seimbangan antara apa yang menjadi harapan rakyat dengan kenyataan kongkrit yang ada, maka hal ini menimbulkan kekecewaan yang mendalam bagi rakyat pada umumnya.

Pelanggaran HAM pada dasarnya dapat terjadi dalam dua cara yaitu bila pelanggaran itu dilakukan oleh negara secara aktif dengan tindakan yang bersifat langsung merugiakan masyarakat, dan pelanggaran hak asasi manusia bila itu dilakukan oleh karena kelalaian yang dilakukan oleh negara yang berakibat merugikan masyarakat. Vitalnya peran negara dalam perlindungan dan pemajuan HAM baik ditinjau dari segi hukum internasional HAM maupun dari segi hukum nasional Indonesia sendiri, sangat berpengaruh pada kondisi negara RI dalam hal perlindungan, pemajuan, pemenuhan dan penghormatan terhadap HAM. Secara yuridis formal pada dasarnya negara dipandang wajib bertanggung jawab penuh terhadap pelanggaran HAM, baik yang dilakukan berdasarkan kebijakan sendiri maupun yang terjadi karena kelalaian melakukan pencegahan.

Issu yang terjadi dalam sebuah alat negara yang seharusnya menjadi tonggak penopang pendukung implementasi hak asasi manusia bagi masyarakat umumnya yaitu badan peradilan justru menyebarkan issu "Mafia Peradilan" yang cenderung banyak merugikan masyarakat umumnya, dan ternyata hal itu telah berlangsung selama betahun- tahun. Bahwa Mafia Peradilan yang ada di Indonesia bukan saja dari swasta, akan tetapi tumbuh dan berasal dari dalam tubuh lembaga negara yaitu badan Peradilan. Hal ini bukan lagi merupakan rahasia bagi masyarakat pada umumnya, tapi permasalahannya telah menadi sebuah upaya penghapusan dan penentangan kegiatan mafia demi upaya implementasi hak asasi manusia secara sebaik- baiknya di masyarakat.

Strategi negara dalam upaya meningkatkan perlindungan dan pemajuan HAM pada dasarnya dapat dilihat dari salah satu kegiatan yang dirancang oleh Badan Perancang Pembangunan Nasional (BAPENAS) berkaitan dengan pembiayaan dan kemampuan keuangan negara.

\section{Penjelasan Kepala BAPENAS}

Strategi Pembangunan Nasional dalam Upaya Meningkatkan Perlindungan dan Pemajuan HAM di seluruh Indonesia pada dasarnya merupakan kewajiban seluruh jajaran birokrasi, yang selanjutnya pelaksanaannya dikasanakan secara bersama- sama dan berkesinambungan dalam sebuah rancangan yang telah ditentukan dan dirancang sesuai dengan kemampuan negara. 
Sebagaimana diketahui bahwa, adanya amandemen UUD 1945 telah meniadakan Garis-garis Besar Haluan Negara (GBHN) dan mengubah sistem pemilihan Presiden melalui mekanisme yang dipilih langsung oleh rakyat. Selanjutnya sebagai implikasi amandemen UUD 1945 tersebut, paradigma perencanaan pembangunan nasional juga telah mengalami perubahan.

Sebelum adanya amandamen UUD 1945, GBHN merupakan dokumen yang menjadi pedoman dalam rangka perencanaan pembangunan nasional. Namun, dengan dilakukannya amandemen UUD 1945, perubahan sistem perencanaan pembangunan nasional kemudian ditandai dengan ditetapkannya Undang-undang Nomor 17 Tahun 2003 tentang Keuangan Negara dan Undangundang Nomor 25 Tahun 2004 tentang Sistem Perencanaan Pembangunan Nasional (SPPN). Dua undang - undang tersebut merupakan payung untuk mengharmonisasikan dan mengkoordinasikan antara perencanaan dan penganggaran pembangunan dalam rangka mewujudkan tujuan bernegara sebagaimana yang tertuang dalam Pembukaan UUD 1945.

Dalam upaya mengimplementasikan 2 (dua) undang-undang tersebut, Kabinet Indonesia Bersatu, yang dibentuk oleh Presiden terpilih hasil pemilu Tahun 2004, telah menetapkan Peraturan Presiden Nomor 7 Tahun 2005 tentang Rencana Pembangunan Jangka Menengah Nasional (RPJM) Tahun 2004-2009, yang pada dasarnya merupakan penjabaran dari visi dan misi Presiden terpilih tersebut.

Visi yang tertuang dalam RPJM terdiri dari tiga hal, yaitu: (1) terwujudnya kehidupan masyarakat, bangsa, dan negara yang aman bersatu, rukun dan damai; (2) terwujudnya masyarakat, bangsa, dan negara yang menjunjung tinggi hukum dan kesetaraan dan hak asasi manusia; dan (3) terwujudnya perekonomian yang mampu menyediakan kesempatan kerja dan penghidupan yang layak serta memberikan fondasi yang kukuh bagi pembangunan yang berkelanjutan.

Selanjutnya, untuk mencapai visi pembangunan tersebut maka dilaksanakan tiga misi, yaitu: (1) mewujudkan Indonesia yang aman dan damai; (2) mewujudkan Indonesia yang adil dan demokratis; dan (3) mewujudkan Indonesia yang sejahtera.

Untuk mewujudkan jangka menengah ini akan ditempuh 2 (dua) strategi pokok pembangunan, yaitu: (1) Strategi Penataan Kembali Indonesia dan (2) Strategi Pembangunan Indonesia. Strategi Penataan Kembali Indonesia diarahkan untuk mengembangkan sistem ketatanegaraan Republik Indonesia yang tangguh sehingga menjadi kuat dalam menghadapi goncangan berbagai perubahan yang terjadi dimasyarakat. Di samping itu strategi ini juga dimaksudkan untuk membangun demokrasi yang tetap dijiwai oleh semangat Pancasila dan Pembukaan UUD 1945, yaitu demokrasi yang selain memberikan hak tetapi juga mengandung unsur tanggung jawab. Strategi kedua, yaitu Strategi Pembangunan Indonesia, diarahkan untuk membangun Indonesia disegala bidang dengan sasaran pokok pemenuhan hak dasar rakyat dan penciptaan landasan pembangunan yang kukuh.

Pemenuhan hak dasar rakyat pada dasarnya mencerminkan penjabaran dari perlindungan dan pemajuan HAM, yaitu perlindungan atas hak sipil dan politik, serta pemenuhan hak ekonomi, sosial dan budaya, penciptaan landasan bangsa Indonesia dan ruang gerak yang lebih baik 
dalam melaksanakan pembangunan yang berkelanjutan.

Strategi Pembangunan Nasional dalam Upaya Meningkatkan Perlindungan dan Pemajuan HAM, pada dasarnya secara langsung terkait dengan salah satu misi yang telah ditetapkan yaitu hal yang terkait erat dengan perlindungan dan pemajuan HAM di Indonesia, dalam hal ini agenda mewujudkan Indonesia yang adil dan demokratis.

Untuk melaksanakan agenda pembangunan tersebut, salah satu sasaran yang hendak dicapai adalah upaya meningkatkan keadilan dan penegakan hukum dalam hal ini diharapkan dapat tercermin dari sistem hukum yang adil, konsekuen, dan tidak diskriminatif serta memberikan perlindungan dan penghormatan kepada hak asasi manusia, dan terwujudnya konsistensi semua peraturan perundang-undangan di tingkat pusat dan daerah. Upaya-upaya tersebut dilakukan sebagai bagian dari langkahlangkah pemulihan kembali kepercayaan masyarakat kepada hukum di Indonesia.

Untuk mencapai sasaran pembangunan tersebut, telah ditetapkan berbagai program pembangunan hukum yang dapat dikelompokkan menjadi 3 (tiga) bidang, yaitu 1). Substansi hukum, 2). Struktur hukum dan 3). Budaya hukum.

1. Substansi hukum atau materi hukum meliputi peraturan perundangundangan dalam bentuk undangundang, peraturan pelaksanaan di bawahnya baik pada tingkat nasional maupun pada tingkat regional / daerah;

2. Struktur hukum meliputi kelembagaan hukum dan aparatur penegak hukum serta dukungan sarana dan prasarananya; dan
3. Budaya hukum yaitu cara pandang masyarakat terhadap norma-norma hukum yang hidup dalam masyarakat yang bersangkutan, termasuk juga tingkat kesadaran hukum masyarakat.

Dari sekian banyak masalah yang dihadapi untuk mempercepat pembangunan subtansi (materi) hukum, yang paling utama dapat diperkirakan secara umum adalah upaya penertiban mengingat masih banyak terdapat peraturan perundangundangan yang saling bertentangan satu dengan yang lain. Sebagai implikasinya kiranya sudah dapat dibayangkan bagaimana sulitnya implementasi dari peraturan perundang - undangan di lapangan, yang umumnya sering ditemukan peraturan perundang-undangan yang berada pada tingkatan lebih rendah, kenyataannya bertentangan dengan peraturan perundang-undangan yang ada di atasnya. Secara fakta dalam pelaksanaannya justru peraturan perundang-undangan yang lebih rendah bisa jadi mempunyai peran besar dan mengesampingkan peraturan perundangundangan di atasnya. Kondisi tersebut apabila secara terus menerus dibiarkan tentu dapat menimbulkan ketidakpastian dan tidak adanya jaminan hukum bagi masyarakat secara keseluruhan.

Dalam kaitannya dengan pengakuan dan perlindungan HAM di Indonesia, sampai dengan saat ini, masih ada beberapa konvensi internasional yang belum diratifikasi oleh Indonesia. Konvensi tersebut antara lain adalah Konvensi Internasional Hak Ekonomi, Sosial dan Budaya, Konvensi Hak Sipil dan Hak Politik, Konvensi Pencegahan dan Penghukuman Kejahatan Genosida dan lain sebagainya. Namun, walaupun Indonesia belum meratifikasi konvensikonvensi tersebut, untuk beberapa peraturan perundang-undangan nasional 
dalam kenyataannya telah mengadopsi prinsip - prinsip pengakuan dan perlindungan HAM sebagaimana yang diatur dalam konvensi internasional tersebut.

Beberapa peraturan perundang-undangan yang dapat dikemukakan disini antara lain adalah UU Nomor 39 tahun 1999 tentang Hak Asasi Manusia, UU Nomor 9 Tahun 1998 tentang Kemerdekaan Menyampaikan Pendapat di Muka Umum. Kepres Nomor 83 Tahun 1998 tentang Pengesahan Konvensi Nomor 87 tentang Kebebasan Berserikat dan Perlindungan Hak untuk Berorganisasi, UU Nomor 19 Tahun 1999 tentang Pengesahan Konvensi 23 Tahun 2002 tentang Perlindungan Anak, UU Nomor 1 Tahun 2000 tentang Pengesahan Konvensi ILO Nomor 182 mengenai Pelarangan dan Tindakan Segera Penghapusan BentukBentuk Pekerjaan Terburuk Anak, dan lain sebagainya.

Dalam upaya implementasi hak asasi manusia melalui Program Pembentukan Hukum diharapkan, kemungkinan permasalahan yang terjadi dilapangan yang terkait dengan subtansi hukum dapat diminimalkan. Malalui kegiatan harmonisasi peraturan perundangundangan nasional diharapkan tidak terjadi lagi pertentangan dan tumpang tindih antara satu peraturan perundangundangan dan peraturan perundangundangan lainnya. Sebagai bagian dari upaya harmonisasi peraturan perundangundangan ini, dilakukan juga kajian dan penelitian terhadap peraturan perundangundangan nasional yang telah ada untuk dapat melihat sejauh mana kemungkinan terjadi konflik dengan prinsip-prinsip perlindungan dan penegakan HAM.

Disamping itu, mengingat masih sangat terbatasnya keikutsertaan Indonesia dalam berbagai konvensi internasional yang terkait dengan perlindungan dan pemajuan HAM, maka langkah dan upaya yang perlu dilakukan antara lain adalah melakukan persiapan ratifikasi sejumlah instrumen HAM internasional yang dianggap penting untuk meningkatkan penghormatan HAM di Indonesia. Persiapan ini meliputi kegiatan pengkajian dan penelitian prinsip-prinsip HAM yang ada dalam konvensi-konvensi internsional dengan tetap melihat pada perspektif kepentingan Indonesia dan peraturan perundang-undangan nasional.

\section{Pemberdayaan Lembaga Penegak Hukum}

Terkait dengan pemberdayaan kelembagaan penegak hukum, ternyata masih cukup banyak masalah yang dihadapi, diantaranya adalah masih rendahnya kinerja lembaga hukum yang ada seperti peradilan, kejaksaan dan kepolisian, yang secara fakta dapat dikatakan bahwa rendahnya kinerja pada lembaga peradilan dapat diuraikan antara lain sebagai sering ditemukan adanya kelambatan dalam proses peradilan, dan hal ini sering dirasakan oleh masyarakat yang kemudian permasalahan selanjutnya adalah seringkali menimbulkan ketidakpastian hukum.

Seringkali terjadi dalam masyarakat pencari keadilan bahwa mereka harus menunggu selama bertahun-tahun untuk mendapatkan putusan yang telah mempunyai kekuatan hukum tetap. Disamping itu, adanya independensi hakim dalam memutus suatu perkara seringkali menimbulkan kritikan karena adanya putusan pengadilan yang dirasakan melanggar rasa keadilan masyarakat. 
Di lembaga Kejaksaan tidak jarang ada kemungkinan penghentian penuntutan oleh pihak kejaksaan tanpa adanya penjelasan yang transparan atas proses penghentian penuntutan yang dapat dipertanggung jawabkan. Hal ini sering kali dilihat sebagai peluang adanya "Permainan" antara aparatur kejaksaan dan pihak yang berperkara, dan kondisi demikian sangat merugikan hak-hak asasi pihak yang terkait khususnya dan masyarakat pada umumnya.

Rencana Aksi Nasional Hak Asasi Manusia Indonesia dimaksudkan sebagai panduan dan rencana umum untuk meningkatkan pengormatan, pemajuan, pemenuhan dan perlindungan hak asasi manusia, termasuk untuk melindungi masyarakat yang rentan terhadap pelanggaran HAM. RANHAM Indonesia sejalan dengan kebijakan nasional dibidang hak asasi manusia, peningkatan kesadaran hukum, dan pengentasan kemiskinan yang mendapat tempat utama dalam pembangunan nasional. Melalui pelaksanaan "Program Peningkatan Kinerja Lembaga Peradilan dan Lembaga Penegak Hukum lainnya" dilakukan langkah-langkah untuk menciptakan transparansi dan akuntabilitas dilingkungan lembaga peradilan, antara lain melalui pembentukan lembaga pengawas independen. Untuk itu masyarakat menaruh harapan yang besar dengan dibentuknya Komisi Yudisial berdasarkan Undang-Undang Nomor 22 Tahun 2004 dengan 7 ( Tujuh) orang anggota Komisi Judisial periode 20052010, yang salah satu tugasnya adalah "Menegakkan kehormatan dan keluhuran martabat serta menjaga perilaku hakim".

Sejalan dengan semangat reformasi yang telah berjalan sejak tahun 1998, pelaksanaan RANHAM dimaksudkan untuk memperkuat budaya penghormatan hak asasi manusia yang akhirnya memperkuat sendi- sendi dasar kehidupan bermasyarakat, bebangsa dan bernegara menuju masyarakat adil dan makmur, dengan program utama untuk tahun 2004 - 2009 yaitu :

1. Pembentukan dan penguatan institusi pelaksana RANHAM;

2. Persiapan ratifikasi instrumen HAM Internasional;

3. Persiapan harmonisasi peraturan perundang- undangan;

4. Diseminasi dan pendidikan HAM;

5. Penerapan norma dan standar HAM;

6. Pemantauan, Evaluasi dan pelaporan.

Sejalan dengan program utama yang telah dicanangkan dalam RANHAM 2004 2009, kemudian disesuaikan dengan upaya pembenahan kelembagaan hukum yang ada, khususnya dalam rangka penegakan hukum dan HAM, perlu ditinjau upayaupaya perbaikan yang mendesak akhirakhir ini antara lain adalah upaya - upaya Penghapusan Eksploitasi Seksual Komersial Anak; dan juga pelaksanaan Rencana Aksi Nasional Penghapusan Bentuk-bentuk Pekerjaan Terburuk untuk Anak. Adanya rencana aksi nasional tersebut diharapkan dapat dijadikan sebagai pegangan bagi setiap instansi pelaksana sesuai dengan tugas dan kewenangan masing-masing untuk mempercepat pelaksanaan HAM di Indonesia.

\section{Kesimpulan}

Adanya peraturan perundang-undangan yang baik saja ternyata tidak cukup untuk dapat menjamin adanya perlindungan, pemajuan dan penegakan HAM di Indonesia. Untuk itu perlu upaya yang juga harus dilakukan yaitu penataan kelembagaan hukum yang meliputi 
institusi dan Sumber Daya Manusia yang teruji kemapuannya.

Upaya untuk memperbaiki kelembagaan hukum ini antara lain adalah dengan dibentuknya pengadilan HAM yang merupakan bagian dari lingkungan peradilan umum termasuk pengangkatan hakim HAM Ad-hoc. Selain itu peningkatan profesionalitas aparatur penegak hukum dalam rangka penegakan HAM perlu terus dilakukan antara lain dengan melakukan pendidikan dan pelatihan yang dilakukan baik melalui kerja sama dengan negara donor maupun pembiayaan dengan APBN dengan pelaksanaan di dalam negeri atau di luar negeri.

Pada dasarnya budaya hukum dari suatu masyarakat merupakan gambaran dari keberhasilan pembangunan subtansi hukum dan struktur hukum dari masyarakat hukum itu sendiri. Pada masyarakat yang peraturan perundangundangannya sudah tertata dengan baik, tumpang tindih dan pertentangan antara satu peraturan perundang-undangan yang lain sudah diminimalkan; pelaksanaan sudah berjalan dengan baik, institusi hukumnya telah menjalankan kewenangannya sesuai dengan ketentuan yang berlaku, didukung oleh aparatur penegak hukum yang profesional dan berintergritas, maka masyarakat dengan sendirinya akan memandang hukum menjadi lebih baik, masyarakat akan lebih patuh kepada hukum, lebih hormat, serta patuh kepada aparatur penegak hukum.

Terkait dengan perlindungan, pemajuan dan penegakan HAM, kendala-kendala yang masih ditemui dalam pelaksanaannya adalah masih banyaknya aparatur negara yang belum memahami prinsip-prinsip perlindungan, pemajuan dan penegakan HAM. Akibat dari situasi tersebut sangat mungkin terjadi akan lebih banyak aparatur negara yang melanggar hak-hak masyarakat melalui Program Peningkatan Kesadaran hukum dan HAM, maka selanjutnya diharapkan permasalahan tersebut dapat diatasi dengan kualitas kinerja aparaturnya ditingkatkan dengan cara optimal memahami permasalahan hak asasi manusia.

Dalam tahun 2005 kegiatan yang akan dilakukan adalah melakukan evaluasi atas metode pengembangan dan peningkatan kesadaran hukum dan hak asasi manusia agar dapat diketahui efektifitas dari kegiatan ini. Disampingkan itu juga dilakukan pembekalan bagi tenaga penyuluh hukum dan hak asasi manusia agar proses penyuluhan dapat lebih tepat sasaran dan mudah dipahami oleh masyarakat.

Dalam kaitannya dengan upaya untuk lebih lebih meningkatkan budaya hukum khususnya kepada aparatur negara, perlu terus dilanjutkan kegiatan sosialisasi dan penyuluhan yang lebih menarik, sederhana dan mudah dipahami. Untuk lebih mengoptimalkan proses sosialisasi dan penyuluhan kepada aparatur negara tersebut, maka perlu dipakai metode sosialisasi yang lebih interaktif baik melalui pendekatan dialogis, media elektronik maupun melalui media massa. Selanjutnya dengan adanya pengkayaan metode pengembangan dan peningkatan kesadaran hukum dan HAM secara terus menerus maka diharapkan pemahaman akan prinsip-prinsip HAM pada aparatur negara pada khususnya dan masyarakat pada umumnya dapat selalu diperbaharui. 
DAFTARA PUSTAKA

1. Undang - Undang Dasar Negara Kesatuan RI.1945;

2. Undang-undang No. 17 tahun 2003 Tentang Keuangan Negara;

3. Undang-Undang No. 25 tahun 2004 Tentang Sistem Perencanaan Pembangunan Nasional;

4. Undang - Undang No. 39 Tahun 1999 Tentang Hak Asasi Manusia;

5. Undang - undang No.9 tahun 1998 Tentang Kemerdekaan menyampaikan Pendapat di depan Umum;

6. Peraturan Presiden RI No. 7 Tahun 2005 Tentang Rencana Pembangunan Jangka Menengah Nasional ( RPJM) 